\title{
Effects of Fatty Acid Supplements on Ruminal and Total Tract Nutrient Digestion in Lactating Dairy Cows
}

\author{
K. J. Harvatine ${ }^{1}$ and M. S. Allen ${ }^{2}$ \\ Department of Animal Science, Michigan State University, East Lansing 48824-1225
}

\begin{abstract}
Saturated and unsaturated fatty acid supplements (FS) were evaluated for effects on ruminal digestion kinetics, and ruminal and postruminal nutrient digestion. Eight early lactation ruminally and duodenally cannulated cows (77 \pm 12 days in milk, mean \pm SD) were used in a replicated $4 \times 4$ Latin square design experiment with 21 -d periods. Treatments were control and a linear substitution of $2.5 \%$ fatty acids from supplemented saturated FS (SAT; prilled, hydrogenated free fatty acids) for partially unsaturated FS (UNS; calcium soaps of long-chain fatty acids). All rations contained identical forage and concentrate components including $37.2 \%$ forage and $13.5 \%$ cottonseed. Saturated FS linearly decreased ruminal digestibility of dry matter and organic matter and linearly decreased ruminal neutral detergent fiber (NDF) digestibility. The reduction in ruminal NDF digestibility was because of a linear decrease in digestion rate and a linear increase in passage rate of potentially digestible NDF with increasing saturated FS. Total tract digestibility of NDF was not different between treatments because of compensatory postruminal digestion. Ruminal fatty acid and C18 fatty acid digestibility tended to increase linearly with increasing unsaturated FS, and postruminal C18 fatty acid digestibility decreased with increasing saturated FS. Saturated FS linearly decreased ruminal organic matter digestibility and decreased intestinal long-chain fatty acid digestibility, although differences in fatty acid digestibility may be partially explained by fatty acid intake.
\end{abstract}

Key words: fatty acid, site of digestion, digestion kinetics, NDF digestion

\section{INTRODUCTION}

Fat is commonly included in diets of dairy cows to increase energy density. Rumen-available fatty acids

\footnotetext{
Received January 13, 2005.

Accepted September 14, 2005.

${ }^{1}$ Current address: Department of Animal Science, Cornell University, Ithaca, NY 14853.

${ }^{2}$ Corresponding author: allenm@msu.edu
}

(FA) from oilseeds, byproducts and tallow, can be used to increase dietary FA concentration up to 3 percentage units with minimal negative effects on microbial growth and rumen function (NRC, 2001). However, unprotected, unsaturated FA are absorbed by rumen bacteria and can be toxic to the microbes unless saturated by biohydrogenation (Harfoot, 1981). Prilled FA and calcium salts of FA are two commercially available FA supplements commonly used to increase dietary FA concentration. Prilled, hydrogenated FA are highly saturated FA developed to decrease interference with microbial fermentation. Calcium salts of long-chain FA are FA complexed with a calcium ion making them insoluble. Microbes cannot absorb FA as calcium salts and FA salts have little effect on microbial fermentation. However, the complex dissociates as ruminal $\mathrm{pH}$ decreases allowing microbial uptake and biohydrogenation (Wu et al., 1991).

Although FA supplements are often used to increase energy density of the diet, their efficacy depends on the digestibility of the added FA and their effect on digestibility of other nutrients. Associative effects of FA may shift the site of nutrient digestion from the rumen to the intestine possibly reducing diet digestibility. Specifically, FA differ in their hypophagic effects (Allen, 2000); decreased intake may decrease ruminal passage rate allowing increased ruminal digestibility. The objective of this experiment was to determine the effects of FS saturation on ruminal digestion kinetics and site and extent of nutrient digestion. We hypothesized that the more unsaturated FS source would decrease feed intake, increasing ruminal retention time and ruminal OM digestibility compared with the saturated FS.

\section{MATERIALS AND METHODS}

This article is the second of a series of 3 articles from one experiment that evaluated effects of FS differing in FA saturation. This article discusses treatment effects on ruminal digestion kinetics and site of digestion, and the companion articles focus on milk production, milk FA profile, and energy balance (Harvatine and Allen, 2006a) and feed intake and feeding and chewing behavior (Harvatine and Allen, 2006b). Experimental procedures were approved by the All University Com- 
mittee on Animal Use and Care at Michigan State University.

\section{Treatments and Cows}

Eight ruminally and duodenally cannulated multiparous Holstein cows ( $77 \pm 8.7 \mathrm{DIM}$; mean \pm SD) from the Michigan State University Dairy Cattle Teaching and Research Center were used in a replicated $4 \times 4$ Latin square design experiment. Cows were randomly assigned to treatment sequence. Treatments were a control diet containing no added FS or FS containing 2.5\% FA from saturated (SAT; prilled hydrogenated free FA, Energy Booster 100, MS Specialty Nutrition, Dundee, IL), an intermediate mixture (50:50) of saturated and unsaturated (INT), or partially unsaturated (UNS; Ca Soaps of LCFA, Megalac-R, Church and Dwight Company, Inc., Princeton, NJ) FA. Treatment periods were $21 \mathrm{~d}$ with the final $11 \mathrm{~d}$ used for sample and data collection. Cows were surgically prepared before calving and duodenal cannulas were a soft gutter type made of Tygon and vinyl tubing (Crocker et al., 1998). The duodenum was fistulated proximal to the pylorus region and prior to the pancreatic duct; cannulas were placed between the 10th and 11th ribs as described by Robinson et al. (1985). Both ruminal and duodenal surgeries were performed at the Department of Large Animal Clinical Science, College of Veterinary Medicine, Michigan State University. Immediately before initiation of the experiment, empty BW (ruminal digesta removed) of cows was $516 \pm 33 \mathrm{~kg}$ (mean $\pm \mathrm{SD}$ ).

Diet components and composition are presented in Table 1 and composition of treatment mixes are presented in a companion paper (Harvatine and Allen, 2006a). Briefly, experimental diets contained $40 \%$ forage (66:33, corn silage: alfalfa silage), $13.5 \%$ whole cottonseed, dry ground corn, premixed protein supplement (soybean meal, corn gluten meal, and blood meal), a mineral and vitamin mix, and $\sim 5.7 \%$ control mix, saturated FS (SAT) mix, 50:50 mix of saturated and unsaturated FS (INT) mixes, or partially unsaturated FS (UNS) mix. The base diet contained 5.5\% FA with 2.5\% FA from whole cottonseed. All diets were fed as a TMR once a day at $0900 \mathrm{~h}$.

\section{Data and Sample Collection}

Cows were housed and fed as previously described (Harvatine and Allen, 2006a). Indigestible NDF was used as a marker to calculate duodenal flow and ruminal digestibility and chromic oxide was used as a marker to calculate digestibility in the total tract. Gelatin capsules (1.5 oz., Tropac Inc., Airfield, NJ) containing $5 \mathrm{~g}$ of chromic oxide and ground spelt hulls
Table 1. Ingredient and nutrient composition of experimental diets ${ }^{1}$

\begin{tabular}{|c|c|c|c|c|}
\hline & Control & SAT & INT & UNS \\
\hline Ingredients & \multicolumn{4}{|c|}{$\longrightarrow \%$ of $\mathrm{DM}$} \\
\hline Corn silage $^{2}$ & 24.6 & 24.7 & 24.7 & 24.6 \\
\hline Alfalfa silage ${ }^{3}$ & 12.6 & 12.6 & 12.6 & 12.6 \\
\hline Ground corn & 28.7 & 28.8 & 28.8 & 28.7 \\
\hline Whole cottonseed & 13.5 & 13.5 & 13.5 & 13.5 \\
\hline Protein $\operatorname{mix}^{4}$ & 10.5 & 10.6 & 10.5 & 10.5 \\
\hline Mineral-vitamin $\operatorname{mix}^{5}$ & 4.3 & 4.3 & 4.3 & 4.3 \\
\hline Control mix ${ }^{6}$ & 5.7 & 0.5 & 0.2 & - \\
\hline SAT mix ${ }^{6}$ & - & 5.0 & 2.5 & - \\
\hline UNS $\operatorname{mix}^{6}$ & - & - & 2.9 & 5.7 \\
\hline \multicolumn{5}{|l|}{ Nutrient } \\
\hline $\mathrm{DM}$ & 55.6 & 55.7 & 55.7 & 55.7 \\
\hline $\mathrm{OM}$ & $92.6^{\mathrm{c}}$ & $92.9^{\mathrm{b}}$ & $93.1^{\mathrm{a}}$ & $93.1^{\mathrm{a}}$ \\
\hline Total fatty acids (FA) & $5.5^{\mathrm{d}}$ & $8.3^{\mathrm{a}}$ & $8.1^{\mathrm{b}}$ & $7.8^{\mathrm{c}}$ \\
\hline Unsaturated FA & $3.6^{\mathrm{d}}$ & $3.9^{\mathrm{a}}$ & $4.4^{\mathrm{b}}$ & $4.9^{\mathrm{c}}$ \\
\hline Starch & $30.8^{\mathrm{a}}$ & $30.3^{\mathrm{c}}$ & $30.5^{\mathrm{bc}}$ & $30.7^{\mathrm{ab}}$ \\
\hline NDF & $29.1^{\mathrm{a}}$ & $27.3^{\mathrm{d}}$ & $27.5^{\mathrm{c}}$ & $27.7^{\mathrm{b}}$ \\
\hline Indigestible NDF & $11.2^{\mathrm{a}}$ & $9.7^{\mathrm{c}}$ & $10.0^{\mathrm{b}}$ & $9.9^{\mathrm{b}}$ \\
\hline Forage NDF & $16.9^{\mathrm{c}}$ & $17.0^{\mathrm{a}}$ & $16.9^{\mathrm{bc}}$ & $17.0^{\mathrm{b}}$ \\
\hline $\mathrm{CP}$ & $16.2^{\mathrm{a}}$ & $16.1^{\mathrm{b}}$ & $16.1^{\mathrm{b}}$ & $16.1^{\mathrm{b}}$ \\
\hline Rumen-undegraded $\mathrm{CP}^{7}$ & $5.1^{\mathrm{a}}$ & $4.8^{\mathrm{d}}$ & $5.1^{\mathrm{b}}$ & $4.9^{\mathrm{c}}$ \\
\hline$\%$ NDF from forage & $57.4^{\mathrm{d}}$ & $61.4^{\mathrm{a}}$ & $60.9^{\mathrm{b}}$ & $60.5^{\mathrm{c}}$ \\
\hline Gross energy, Mcal/kg & $4.55^{\mathrm{b}}$ & $4.72^{\mathrm{a}}$ & $4.72^{\mathrm{a}}$ & $4.71^{\mathrm{a}}$ \\
\hline
\end{tabular}

${ }^{\mathrm{a}-\mathrm{d}}$ Nutrient composition of TMR samples each period $(\mathrm{n}=4$ for each treatment). Means with different superscripts differ $(P<0.05)$.

${ }^{1}$ Treatments were SAT $=$ saturated fatty acids $(\mathrm{FA})$ from prilled, hydrogenated FA; INT = intermediate saturated FA as a mix of prilled, hydrogenated FA and calcium soaps of long-chain FA (LCFA); and UNS = partially unsaturated FA fed as Ca soaps of LCFA.

${ }^{2}$ Corn silage contained $34.7 \% \mathrm{DM}$ (as fed), and $43.4 \% \mathrm{NDF}, 8.4 \%$ $\mathrm{CP}, 10.7 \%$ indigestible NDF, $24.1 \%$ starch, and $4.8 \%$ ash on a DM basis.

${ }^{3}$ Alfalfa silage contained $36.3 \% \mathrm{DM}$ (as fed) and $48.1 \% \mathrm{NDF}, 16.2 \%$ $\mathrm{CP}, 25.7 \%$ indigestible NDF, $2.6 \%$ starch, and $9.7 \%$ ash on a DM basis.

${ }^{4}$ Protein mix contained $74.1 \%$ soybean meal, $20.1 \%$ corn gluten meal, and $5.8 \%$ blood meal.

${ }^{5}$ Mineral-vitamin mix contained $12.7 \%$ sodium bicarbonate, $11.5 \%$ limestone, $5.5 \%$ salt, $2.2 \%$ trace mineral premix, $2.0 \%$ urea, $2.0 \%$ dicalcium phosphate, $0.6 \%$ vitamin $\mathrm{D}, 0.48 \%$ vitamin $\mathrm{A}, 0.12 \%$ vita$\min \mathrm{E}$, and $62.9 \%$ dry ground corn as a carrier.

${ }^{6}$ Control mix contained $50.5 \%$ rice hulls, $16.7 \%$ limestone, and $32.7 \%$ ground corn; SAT mix contained $50.5 \%$ prilled, hydrogenated FA, $16.7 \%$ limestone, and $32.7 \%$ ground corn; and UNS mix contained $57.5 \%$ calcium salts of FA, $10.9 \%$ rice hulls, and $31.6 \%$ ground corn.

${ }^{7}$ Rumen-undegraded protein estimated using values from NRC (2001).

(Wiley mill, 2-mm screen; Authur H. Thomas, Philadelphia, PA) were dosed through the ruminal cannula at 0700,1500 , and $2300 \mathrm{~h}$ (total of $15 \mathrm{~g}$ of $\mathrm{Cr}_{2} \mathrm{O}_{3} / \mathrm{d}$ ) from 7 to $14 \mathrm{~d}$ with a priming dose of $3 \times$ on $\mathrm{d} 7$. Duodenal samples $(1,000 \mathrm{~g})$, fecal samples $(500 \mathrm{~g})$, and rumen fluid samples $(100 \mathrm{~mL})$ were collected every $9 \mathrm{~h}$ from d 12 to 14 so that 8 samples were taken for each cow each period, representing every $3 \mathrm{~h}$ of a $24-\mathrm{h}$ period to account for diurnal variation. Rumen fluid samples were obtained by combining and straining digesta from 5 different sites in the rumen. All samples were immediately frozen at $-20^{\circ} \mathrm{C}$. 
Ruminal contents were evacuated manually through the ruminal cannula at $1350 \mathrm{~h}$ ( $4.5 \mathrm{~h}$ after feeding) on $\mathrm{d} 20$ and at $0700 \mathrm{~h}$ ( $2 \mathrm{~h}$ before feeding) on $\mathrm{d} 21$ of each period. Total ruminal content mass and volume were determined. During evacuation, $10 \%$ aliquots of digesta were separated to allow accurate sampling. Aliquots were squeezed through a nylon screen (1-mm pore size) to separate into primarily solid and liquid phases. Samples were taken from both phases for determination of nutrient pool size.

\section{Sample and Statistical Analyses}

Forages and orts were coarse ground with dry ice, lyophilized (TriPhilizer MP, FTS Systems, Stone Ridge, NY), and then finely ground. Rumen solid and liquid fractions were lyophilized and recombined based on original DM ratio of solid and liquid fractions. Duodenal digesta was similarly split into solid and liquid fractions, subsampled, lyophilized, and recombined based on the DM ratio of the fractions. Fecal samples were lyophilized, ground using a Wiley mill (1-mm screen) and combined on an equal DM basis into one sample per cow per period. A portion of all samples was placed in a Whirl-Pak bag (Nasco, Fort Atkinson, WI) flushed with nitrogen gas and frozen for FA analysis to minimize FA oxidation.

All dried samples were analyzed for DM, ash, NDF, 240-h in vitro indigestible NDF (iNDF), CP, starch, gross energy, and FA concentration and profiles. Ash concentration was determined after a 5 -h oxidation at $500^{\circ} \mathrm{C}$ in a muffle furnace. Concentration of NDF was according to Van Soest et al. (1991, method A). Indigestible NDF was estimated as NDF residue after 240-h in vitro fermentation (Goering and Van Soest, 1970), and potentially digestible NDF (pdNDF) was calculated by difference. Rumen fluid for in vitro incubations was collected from a nonpregnant dry cow fed only alfalfa hay. Fraction of pdNDF was calculated by difference (1.00 - iNDF). Crude protein was analyzed according to Hach et al. (1987). Starch was measured by an enzymatic method (Karkalas, 1985) after samples were gelatinized with sodium hydroxide. Glucose concentration was measured using a glucose oxidase method (Glucose kit \#510; Sigma Chemical Co., St. Louis, MO), and absorbance was determined with a microplate reader (SpectraMax 190, Molecular Devices Corp., Sunnyvale, CA). Gross energy was assayed by bomb calorimeter (Parr Instrument Inc., Moline, IL). Rumen fluid was analyzed for concentration of major VFA and lactate by HPLC (Waters Corp., Milford, MA) according to Oba and Allen (2003a). Fatty acids were extracted according to Sukhija and Palmquist (1988), and quantified by gas chromatography (model 8500, Perkin-Elmer Corp.,
Norwalk, CT), using a SP-2560 capillary column (100 $\mathrm{m} \times 0.20 \mathrm{~mm}$ i.d. with $0.02-\mu \mathrm{m}$ film thickness; Supelco, Bellefonte, PA). Oven temperature was $140^{\circ} \mathrm{C}$ for $5 \mathrm{~min}$, then increased by $4^{\circ} \mathrm{C} / \mathrm{min}$ to $240^{\circ} \mathrm{C}$ and held for 15 min. Helium flow was $20 \mathrm{~cm} / \mathrm{s}$. Concentrations of all nutrients except DM were expressed as percentages of $\mathrm{DM}$ determined by drying at $105^{\circ} \mathrm{C}$ in a forced-air oven for more than $8 \mathrm{~h}$.

Fecal samples were analyzed for concentration of chromium. Samples were digested with phosphoric acid (Williams et al., 1962), and chromium was quantified by flame atomic absorption spectrometry (SpectraAA 220 , Varian, Victoria, Australia) according to the manufacturer's recommendation. Nutrient intake was calculated using the composition of feed offered and refused on d 11 to 14. Ruminal pool sizes of nutrients were determined by multiplying the concentration of each component by the ruminal digesta DM mass. Turnover rate in the rumen, passage rate from the rumen, and ruminal digestion rate of each component were calculated according to Oba and Allen (2003b).

To determine differences between treatments, all data were analyzed using the fit model procedure of JMP (Version 5, SAS Institute, Cary, NC) according to the following model:

$$
\mathrm{Y}_{\mathrm{ijk}}=\mu+\mathrm{C}_{\mathrm{i}}+\mathrm{P}_{\mathrm{j}}+\mathrm{T}_{\mathrm{k}}+\mathrm{e}_{\mathrm{ijk}}
$$

where $Y_{i j k}=$ dependent variable, $\mu=$ overall mean, $C_{i}=$ random effect of cow ( $i=1$ to 8$), P_{j}=$ fixed effect of period $(\mathrm{j}=1$ to 4$), \mathrm{T}_{\mathrm{k}}=$ fixed effect of treatment $(\mathrm{k}=1$ to 4$)$, and $\mathrm{e}_{\mathrm{ijk}}=$ residual error.

Period by treatment interaction was evaluated, but was removed from the statistical model when not significant $(P>0.10)$. Period by treatment interaction was not significant for any variable of primary interest; variables with significant interactions are noted in the tables. Data points with Studentized Residuals greater than 3 were considered outliers and excluded from analysis. Few points were excluded in analysis and rarely more than one per response variable. Preplanned contrasts included the effect of addition of FS (control vs. SAT, INT, and UNS), linear effect of substituting unsaturated FA for saturated FA (SAT vs. UNS), and quadratic effect of substituting unsaturated FA for saturated FA (INT vs. SAT and UNS). The preplanned contrasts do not allow individual comparison of each fat treatment to the control. Protected LSD was used for mean separation for some parameters of main interest when there was an overall effect of rumen-supplemented fat and a significant effect of FA type. Pearson correlation coefficients were determined between cowperiod observations for some parameters. Treatment effects, linear and quadratic responses, and correlations 
were declared significant at $P<0.05$, and tendencies were declared at $P<0.10$. Data from 2 cow-periods were excluded from statistical analysis. One cannulated cow developed clinical mastitis on d 19 of period 3; rumen samples, BW, and BCS were not collected for this period. Data previously collected in this period were included in our analysis. The cow did not fully recover and data from period 4 were not used.

\section{RESULTS AND DISCUSSION}

Treatment diet ingredient content and nutrient composition are reported in Table 1 . Diets contained the same base ration and differed in FS containing 2.5\% FA or rice hulls only. Control diet contained 5.5\% FA and FS diets contained 8.3, 8.1, and 7.8\% FA for SAT, INT, and UNS, respectively. Dietary unsaturated FA density increased from SAT to UNS (3.9, 4.4, and 4.9\% for SAT, INT, and UNS, respectively).

\section{Intake}

Addition of FS decreased DMI, and increasing unsaturated FS linearly decreased intake within FS. Intake of other nutrients including NDF, pdNDF, starch, and $\mathrm{CP}$ followed the same response pattern. Intake and feeding behavior are discussed in a companion paper (Harvatine and Allen, 2006b).

\section{Flow Marker}

Indigestible NDF was used as the flow marker for calculation of duodenal flow and chromic oxide was used for determination of fecal flow. Chromic oxide was intended for prediction of duodenal flow, but resulted in unrealistically high duodenal flow, presumably due to difficulty in subsampling of duodenal liquid. Use of iNDF has the potential to cause treatment bias because of effects of duodenal FA on in vitro fermentation for determination of indigestible residue. To ensure that this was not the case, we also calculated duodenal and fecal flow for all cow periods using acid detergent-sulfuric acid lignin as well as 120-h indigestible ADF after ether extraction. These markers provided results similar to flow and digestibility calculated with iNDF. Chromic oxide was used as the total tract fecal marker because it was not affected by subsampling.

\section{Ruminal Carbohydrate Digestion}

Saturated FS linearly decreased apparent ruminal $\mathrm{DM}$ and $\mathrm{OM}$ digestibility (Table 2) and reduced ruminal NDF digestibility (Table 3). Apparent ruminal digestibility of starch was not affected by FA saturation. In- creasing saturated FS reduced the amount of DM and tended to reduce the amount of OM and NDF digested in the rumen, but did not affect the amount of starch digested. Addition of FS did not affect apparent ruminal digestibility of DM, OM, NDF, or starch but decreased the amounts of OM and starch apparently digested in the rumen because of a reduction in DMI (Tables 2, 3, and 4).

Fatty acid supplements decreased ruminal VFA concentration and changed VFA profile by decreasing acetate and increasing propionate concentrations (Table 5). Total ruminal VFA concentration tended to decrease linearly with increasing saturated FS, and the molar proportion of acetate tended to decrease and branchedchain VFA proportion increased with increasing saturated FS. Decreased total VFA concentration is consistent with the reduction in apparent ruminal OM digestibility or possible differences in ruminal motility (not measured) affecting VFA absorption, or both.

The reduction in ruminal OM digestibility with SAT was not expected because saturated FA are not expected to interfere with microbial fermentation. In vitro fermentations with addition of free stearic acid at $10 \%$ of DM was not different from esterified stearic acid, although fermentation was decreased with free palmitic and oleic FA (Chalupa et al., 1984). Although higher concentrations of free stearic acid, ranging from 10 to $20 \%$ of DM, resulted in a linear decrease of VFA production (Chalupa et al., 1984), these are much higher FA concentrations than observed in the rumen in this experiment (Harvatine and Allen, 2006c), and the authors noted low metal cation concentration in the buffer that were expected to limit formation of FA salts. Although most reports of prilled, hydrogenated free FA have shown no effect on total tract nutrient digestion in lactating dairy cows (Schauff and Clark, 1989; Palmquist, 1991; Elliott et al., 1996), there is some evidence of a reduction in ruminal or total tract digestibility by prilled, hydrogenated FA. Grummer (1988) observed decreased total tract NDF digestibility with a low inclusion rate $(0.68 \mathrm{~kg} / \mathrm{d})$ of prilled, hydrogenated FA compared with a low-fat control, although ruminal VFA concentration and in situ DM and NDF digestion rates were not affected, and there were no effects on digestibility with a high FA inclusion rate $(0.91 \mathrm{~kg} / \mathrm{d})$. Saturated free FA compared with low-fat and esterified saturated FA decreased ruminal OM digestibility in steers (Elliott et al., 1997), and total tract DM digestibility of lactating cows (Eastridge and Firkins, 1991), but had no effect on ruminal digestion in lactating dairy cows (Chan et al., 1997). In the current study, it appears that SAT decreased ruminal digestibility via alterations of rumen passage rates as discussed below. 
Table 2. Effects of fatty acid supplements varying in saturation on digestion of DM and OM

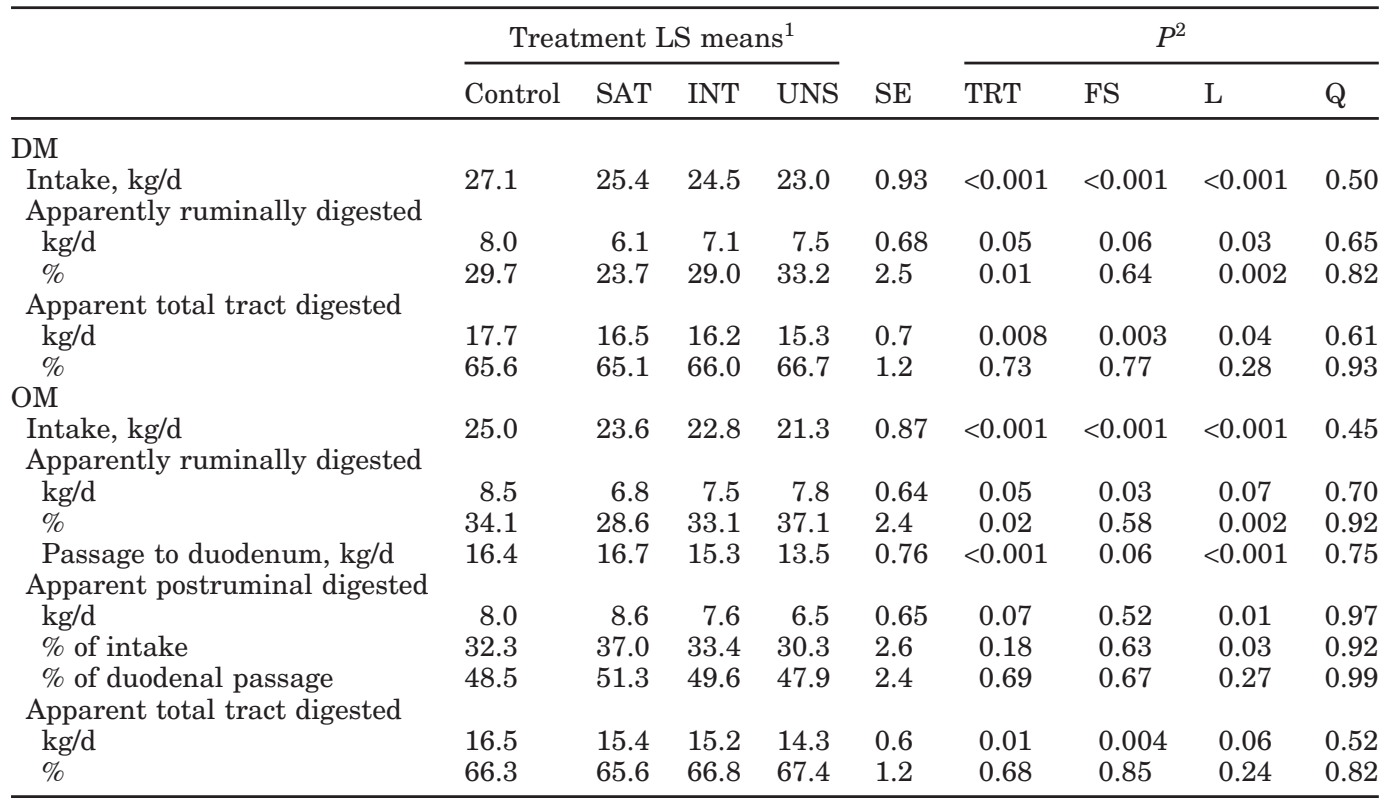

${ }^{1}$ Treatments were SAT $=$ saturated fatty acids $(\mathrm{FA})$ from prilled, hydrogenated FA; INT = intermediate saturated FA as a mix of prilled, hydrogenated FA and calcium soaps of long-chain FA (LCFA); and UNS = partially unsaturated FA fed as Ca soaps of LCFA.

${ }^{2}$ Trt = Treatment effect; FS = effect of FA supplement; L = linear effect of substituting unsaturated FA for saturated FA; and $\mathrm{Q}$ = quadratic effect of substituting unsaturated FA for saturated FA.

\section{Ruminal Digestion Kinetics}

Saturated FS decreased the fractional digestion rate and linearly increased the fractional passage rate of pdNDF (Table 6). Increasing passage rate and decreasing digestion rate resulted in a linear decrease of up to $24 \%$ for ruminal digestibility of pdNDF by SAT (Table 3 ). Contrary to its effects on pdNDF, saturated FS linearly decreased iNDF passage rate. Opposite effects on pdNDF and iNDF passage rates might be related to the effect of saturated FA on chewing behavior. Saturated FS linearly increased rumination time per day and rumination time per kilogram of DMI, and cows on SAT treatment ruminated over 50 min more per day than did cows on control and UNS (Harvatine and Allen, 2006b). Size and density of digesta particles are constraints to passage from the rumen, and are affected by chewing and fermentation (Allen, 1996). Increased rumination is expected to increase particle size reduction rate as well as increase rumen movements and sorting of small particles entrapped in the fibrous mat increasing their rate of escape from the rumen (Allen, 1996). Increased rumination for SAT may have increased escape of particles containing more rapidly digested NDF, explaining the greater passage rate of pdNDF and a slower digestion rate for the pdNDF remaining in the rumen. The slower rate of fermentation may increase particle buoyancy in the rumen and decrease iNDF passage rate (Allen, 1996).

Ruminal FA turnover was increased by FS, but no differences were detected for fractional rates of passage and digestion of total FA. Ruminal turnover of DM, OM, NDF, pdNDF, and starch were not affected by FS or FA saturation. Ruminal FA pool size, and FA biohydrogenation and passage kinetics are reported elsewhere (Harvatine and Allen, 2006c).

\section{Postruminal Digestion}

Treatments did not affect postruminal digestibility of OM, NDF, pdNDF, and starch as a percentage of duodenal flow (Tables 2, 3, and 4). Decreased duodenal $\mathrm{OM}$ flow decreased the amount of OM and tended to decrease the amount of starch digested postruminally with increasing unsaturated FS. Saturated FS linearly increased postruminal digestibility of $\mathrm{DM}$ and $\mathrm{OM}$ as a percentage of intake, representing a shift in site of digestion from the rumen toward the intestine. Increased postruminal digestion with SAT is consistent with compensatory nutrient digestion in the intestine and hindgut.

\section{Total Tract Digestion}

Fatty acid supplement and FA saturation had no effect on total tract DM, OM, NDF, or starch digestibility 
Table 3. Effects of fatty acid supplements varying in saturation on digestion of total NDF and potentially digestible NDF (pdNDF)

\begin{tabular}{|c|c|c|c|c|c|c|c|c|c|}
\hline & \multicolumn{4}{|c|}{ Treatment LS means $^{1}$} & \multirow[b]{2}{*}{$\mathrm{SE}$} & \multicolumn{4}{|c|}{$P^{2}$} \\
\hline & Control & SAT & INT & UNS & & TRT & FS & $\mathrm{L}$ & Q \\
\hline \multicolumn{10}{|l|}{ NDF } \\
\hline Intake, kg/d & 7.5 & 6.8 & 6.7 & 6.1 & 0.6 & $<0.001$ & $<0.001$ & 0.005 & 0.37 \\
\hline \multicolumn{10}{|l|}{ Ruminally digested } \\
\hline $\mathrm{kg} / \mathrm{d}$ & 2.2 & 1.7 & 1.9 & 2.0 & 0.17 & 0.13 & 0.08 & 0.10 & 0.87 \\
\hline$\%$ & 28.8 & 24.6 & 27.8 & 32.2 & 2.0 & 0.04 & 0.78 & 0.006 & 0.80 \\
\hline Passage to duodenum, $\mathrm{kg} / \mathrm{d}$ & 5.3 & 5.1 & 4.9 & 4.2 & 0.18 & $<0.001$ & 0.004 & $<0.001$ & 0.29 \\
\hline \multicolumn{10}{|l|}{ Postruminally digested } \\
\hline $\mathrm{kg} / \mathrm{d}$ & 0.81 & 0.99 & 1.00 & 0.55 & 0.22 & 0.36 & 0.89 & 0.13 & 0.37 \\
\hline$\%$ of intake & 10.8 & 15.0 & 14.5 & 8.9 & 3.2 & 0.42 & 0.59 & 0.15 & 0.51 \\
\hline$\%$ of duodenal flow & 15.0 & 19.5 & 20.1 & 12.8 & 4.1 & 0.50 & 0.61 & 0.23 & 0.43 \\
\hline \multicolumn{10}{|l|}{ Total tract digested } \\
\hline $\mathrm{kg} / \mathrm{d}$ & 3.0 & 2.70 & 2.85 & 2.56 & 0.19 & 0.36 & 0.18 & 0.57 & 0.29 \\
\hline$\%$ of intake & 39.9 & 39.6 & 42.5 & 41.1 & 2.5 & 0.78 & 0.67 & 0.63 & 0.43 \\
\hline \multicolumn{10}{|l|}{ pdNDF } \\
\hline Intake, kg/d & 4.5 & 4.4 & 4.2 & 4.0 & 0.18 & 0.02 & 0.03 & 0.02 & 0.69 \\
\hline \multicolumn{10}{|l|}{ Ruminally digested } \\
\hline $\mathrm{kg} / \mathrm{d}$ & 2.2 & 1.7 & 1.9 & 2.0 & 0.17 & 0.13 & 0.08 & 0.10 & 0.87 \\
\hline$\%$ & 47.8 & 38.5 & 43.9 & 50.5 & 3.0 & 0.03 & 0.30 & 0.006 & 0.86 \\
\hline Passage to duodenum, $\mathrm{kg} / \mathrm{d}$ & 2.3 & 2.6 & 2.4 & 1.9 & 0.12 & 0.004 & 0.92 & $<0.001$ & 0.56 \\
\hline \multicolumn{10}{|l|}{ Postruminally digested } \\
\hline $\mathrm{kg} / \mathrm{d}$ & 0.66 & 0.77 & 0.95 & 0.50 & 0.19 & 0.36 & 0.73 & 0.28 & 0.17 \\
\hline$\%$ of intake & 15.5 & 18.6 & 22.8 & 13.1 & 4.3 & 0.40 & 0.59 & 0.34 & 0.19 \\
\hline$\%$ of duodenal passage & 26.4 & 28.8 & 40.5 & 26.7 & 0.72 & 0.47 & 0.50 & 0.82 & 0.16 \\
\hline \multicolumn{10}{|l|}{ Total tract digested } \\
\hline $\mathrm{kg} / \mathrm{d}$ & 2.8 & 2.5 & 2.8 & 2.5 & 0.19 & 0.38 & 0.25 & 0.90 & 0.19 \\
\hline$\%$ of intake & 62.8 & 57.1 & 65.7 & 63.6 & 3.6 & 0.31 & 0.86 & 0.17 & 0.19 \\
\hline
\end{tabular}

${ }^{1}$ Treatments were SAT $=$ saturated fatty acids (FA) from prilled, hydrogenated FA; INT = intermediate saturated FA as a mix of prilled, hydrogenated FA and calcium soaps of long-chain FA (LCFA); and UNS = partially unsaturated FA fed as Ca soaps of LCFA.

${ }^{2}$ Trt = Treatment effect; FS = effect of FA supplement; L = linear effect of substituting unsaturated FA for saturated FA; and $\mathrm{Q}$ = quadratic effect of substituting unsaturated FA for saturated FA.

because of compensatory postruminal digestion. The SAT treatment numerically decreased DM, OM, NDF, and pdNDF total tract digestibility compared with INT and UNS, providing support for decreased ruminal di- gestibility, especially because total tract and ruminal digestibilities were determined using independent markers (Tables 7 and 8). Although FA digestibility linearly decreased with increasing SAT (Table 8), the

Table 4. Effects of fatty acid supplements varying in saturation on digestion of starch

\begin{tabular}{|c|c|c|c|c|c|c|c|c|c|}
\hline & \multicolumn{4}{|c|}{ Treatment LS means $^{1}$} & \multirow[b]{2}{*}{$\mathrm{SE}$} & \multicolumn{4}{|c|}{$P^{2}$} \\
\hline & Control & SAT & INT & UNS & & TRT & FS & $\mathrm{L}$ & Q \\
\hline Intake, $\mathrm{kg} / \mathrm{d}$ & 8.5 & 7.6 & 7.4 & 7.0 & 0.30 & $<0.001$ & $<0.001$ & 0.001 & 0.45 \\
\hline \multicolumn{10}{|l|}{ Apparently ruminally digested } \\
\hline $\mathrm{kg} / \mathrm{d}$ & 5.0 & 4.3 & 4.6 & 4.2 & 0.36 & 0.02 & 0.007 & 0.67 & 0.11 \\
\hline$\%$ & 58.2 & 55.7 & 61.6 & 59.7 & 3.5 & 0.39 & 0.78 & 0.24 & 0.21 \\
\hline Passage to duodenum, kg/d & 3.5 & 3.4 & 2.8 & 2.8 & 0.26 & 0.04 & 0.04 & 0.06 & 0.23 \\
\hline \multicolumn{10}{|l|}{ Apparent postruminal digested } \\
\hline $\mathrm{kg} / \mathrm{d}$ & 3.0 & 2.9 & 2.4 & 2.4 & 0.26 & 0.07 & 0.09 & 0.07 & 0.17 \\
\hline$\%$ of intake & 35.8 & 38.8 & 32.5 & 34.9 & 3.6 & 0.37 & 0.89 & 0.26 & 0.18 \\
\hline$\%$ of duodenal flow & 84.8 & 87.1 & 83.6 & 86.0 & 1.8 & 0.38 & 0.63 & 0.59 & 0.12 \\
\hline \multicolumn{10}{|l|}{ Apparent total tract digested } \\
\hline $\mathrm{kg} / \mathrm{d}$ & 8.0 & 7.2 & 7.0 & 6.6 & 0.3 & $<0.001$ & $<0.001$ & 0.003 & 0.59 \\
\hline$\%$ & 94.0 & 94.5 & 94.2 & 94.5 & 0.43 & 0.67 & 0.35 & 0.95 & 0.44 \\
\hline
\end{tabular}

${ }^{1}$ Treatments were SAT = saturated fatty acids $(\mathrm{FA})$ from prilled, hydrogenated FA; INT = intermediate saturated FA as a mix of prilled, hydrogenated FA and calcium soaps of long-chain FA (LCFA); and UNS = partially unsaturated FA fed as Ca soaps of LCFA.

${ }^{2}$ Trt = Treatment effect; FS = effect of FA supplement; L = linear effect of substituting unsaturated FA for saturated FA; and $\mathrm{Q}$ = quadratic effect of substituting unsaturated FA for saturated FA. 
Table 5. Effects of fatty acid supplements varying in saturation on ruminal fermentation

\begin{tabular}{|c|c|c|c|c|c|c|c|c|c|}
\hline & \multicolumn{4}{|c|}{ Treatment LS means $^{1}$} & \multirow[b]{2}{*}{$\mathrm{SE}$} & \multicolumn{4}{|c|}{$P^{2}$} \\
\hline & Control & SAT & INT & UNS & & TRT & FS & $\mathrm{L}$ & $\mathrm{Q}$ \\
\hline Total VFA, mM & 140 & 133 & 135 & 138 & 2.0 & $<0.05$ & $<0.001$ & $<0.10$ & 0.92 \\
\hline Lactate, $\mathrm{m} M$ & 0.10 & 0.50 & 0.19 & 0.67 & 0.17 & 0.07 & 0.005 & 0.45 & $<0.05$ \\
\hline \multicolumn{10}{|l|}{ VFA, mol/100 mol } \\
\hline Acetate & 52.5 & 49.3 & 49.8 & 50.2 & 0.50 & $<0.001$ & $<0.001$ & 0.09 & 0.87 \\
\hline Propionate & 32.1 & 33.9 & 34.0 & 33.4 & 0.53 & 0.007 & $<0.001$ & 0.30 & 0.34 \\
\hline Butyrate & 11.1 & 11.5 & 11.4 & 11.8 & 0.25 & 0.17 & $<0.001$ & 0.32 & 0.26 \\
\hline Branched-chain VFA & 4.7 & 5.3 & 4.8 & 4.7 & 0.17 & 0.04 & $<0.001$ & 0.01 & 0.42 \\
\hline Acetate:propionate & 1.64 & 1.46 & 1.47 & 1.51 & 0.04 & $<0.001$ & $<0.001$ & 0.19 & 0.61 \\
\hline
\end{tabular}

\footnotetext{
${ }^{1}$ Treatments were SAT $=$ saturated fatty acids (FA) from prilled, hydrogenated FA; INT = intermediate saturated FA as a mix of prilled, hydrogenated FA and calcium soaps of long-chain FA (LCFA); and UNS = partially unsaturated FA fed as Ca soaps of LCFA.

${ }^{2}$ Trt = Treatment effect; FS = effect of FA supplement; L = linear effect of substituting unsaturated FA for saturated FA; and Q = quadratic effect of substituting unsaturated FA for saturated FA.
}

effect was too small to alter postruminal energy digestiblity of the diets (Table 7).

\section{Fatty Acid Digestion}

Fatty acid supplement increased, and increasing saturated FS linearly increased total, C16, and C18 FA intake (Tables 8 and 9). Increasing unsaturated FS linearly decreased duodenal C18:0 concentration and linearly increased duodenal C18:1, C18:2, and C18:3 concentrations (Harvatine and Allen, 2006c). Fatty acid supplement did not affect total or C18 ruminal FA digestibility, but increased C16 FA ruminal digestibility.
Increasing unsaturated FS tended to linearly increase ruminal digestibility of total and C18 FA.

Loss of dietary FA from the rumen through absorption across the rumen wall and oxidative metabolism is often considered minimal, and bacterial synthesis of FA is commonly expected to produce a net positive flow of FA through the rumen. Low ruminal absorption and metabolism of FA was first concluded with minimal plasma recovery of labeled carbon after ruminal infusion of radioisotope-labeled linoleic acid while diverting nutrients with a reentrant cannula (as discussed by Jenkins, 1993). In addition, microbial FA synthesis was reported during in vitro fermentation (Wu and Palm-

Table 6. Effects of fatty acid supplements varying in saturation on ruminal digestion kinetics

\begin{tabular}{|c|c|c|c|c|c|c|c|c|c|}
\hline & \multicolumn{4}{|c|}{ Treatment LS means $^{1}$} & \multirow[b]{2}{*}{$\mathrm{SE}$} & \multicolumn{4}{|c|}{$P^{2}$} \\
\hline & Control & SAT & INT & UNS & & TRT & FS & $\mathrm{L}$ & Q \\
\hline \multicolumn{10}{|c|}{ Ruminal passage rate, $\% / \mathrm{h}$} \\
\hline Starch & 14.8 & 14.5 & 12.5 & 11.7 & 1.6 & 0.29 & 0.22 & 0.14 & 0.71 \\
\hline $\mathrm{pdNDF}^{3}$ & 2.6 & 3.1 & 2.7 & 2.4 & 0.22 & 0.16 & 0.66 & 0.03 & 0.81 \\
\hline INDF & 3.1 & 2.5 & 2.8 & 3.0 & 0.15 & 0.04 & 0.06 & 0.02 & 0.74 \\
\hline Total FA & 6.4 & 7.3 & 7.4 & 6.5 & 0.36 & 0.14 & 0.16 & 0.11 & 0.26 \\
\hline \multicolumn{10}{|c|}{ Ruminal digestion rate $\% / \mathrm{h}$} \\
\hline Starch & 19.8 & 18.0 & 20.4 & 17.8 & 1.8 & 0.59 & 0.58 & 0.91 & 0.22 \\
\hline pdNDF & 2.4 & 1.8 & 2.2 & 2.4 & 0.2 & 0.12 & 0.21 & 0.04 & 0.81 \\
\hline Total FA & 0.31 & 0.60 & 0.74 & 1.43 & 0.37 & 0.17 & 0.15 & 0.11 & 0.54 \\
\hline \multicolumn{10}{|c|}{ Ruminal turnover rate, $\% / \mathrm{h}$} \\
\hline $\mathrm{DM}$ & 7.8 & 7.4 & 7.3 & 7.6 & 0.27 & 0.57 & 0.32 & 0.43 & 0.58 \\
\hline OM & 7.8 & 7.4 & 7.4 & 7.7 & 0.27 & 0.53 & 0.27 & 0.46 & 0.56 \\
\hline NDF & 4.0 & 3.6 & 3.8 & 3.9 & 0.16 & 0.30 & 0.19 & 0.17 & 0.92 \\
\hline pdNDF & 5.1 & 4.9 & 4.8 & 4.8 & 0.33 & 0.92 & 0.53 & 0.87 & 0.86 \\
\hline INDF & 3.1 & 2.5 & 2.8 & 3.0 & 0.14 & 0.03 & 0.04 & 0.02 & 0.96 \\
\hline Starch & 34.5 & 32.7 & 31.8 & 29.5 & 2.4 & 0.49 & 0.25 & 0.34 & 0.79 \\
\hline Total FA & 6.8 & 8.1 & 7.9 & 7.8 & 0.32 & 0.03 & 0.005 & 0.60 & 0.93 \\
\hline
\end{tabular}

\footnotetext{
${ }^{1}$ Treatments were SAT $=$ saturated fatty acids $(\mathrm{FA})$ from prilled, hydrogenated FA; INT = intermediate saturated FA as a mix of prilled, hydrogenated FA and calcium soaps of long-chain FA (LCFA); and UNS = partially unsaturated FA fed as Ca soaps of LCFA.

${ }^{2}$ Trt = Treatment effect; FS = effect of FA supplement; L = linear effect of substituting unsaturated FA for saturated FA; and Q = quadratic effect of substituting unsaturated FA for saturated FA.

${ }^{3} \mathrm{pdNDF}=$ Potentially digestible NDF.
} 
Table 7. Effects of fatty acid supplements varying in saturation on digestion of energy

\begin{tabular}{|c|c|c|c|c|c|c|c|c|c|}
\hline & \multicolumn{4}{|c|}{ Treatment LS means $^{1}$} & \multirow[b]{2}{*}{ SE } & \multicolumn{4}{|c|}{$P^{2}$} \\
\hline & Control & SAT & INT & UNS & & TRT & FS & $\mathrm{L}$ & Q \\
\hline \multicolumn{10}{|l|}{ Energy } \\
\hline $\begin{array}{l}\text { Intake, Mcal of gross energy/d } \\
\text { Apparent total tract digested }\end{array}$ & 122.8 & 119.8 & 115.4 & 107.8 & 4.4 & 0.001 & 0.001 & 0.001 & 0.47 \\
\hline $\mathrm{Mcal} / \mathrm{d}$ & 78.0 & 75.3 & 74.0 & 70.1 & 3.1 & 0.07 & 0.04 & 0.06 & 0.59 \\
\hline$\%$ & 63.7 & 62.9 & 64.1 & 65.1 & 1.2 & 0.52 & 0.80 & 0.15 & 0.94 \\
\hline
\end{tabular}

${ }^{1}$ Treatments were SAT = saturated fatty acids (FA) from prilled, hydrogenated FA; INT = intermediate saturated FA as a mix of prilled, hydrogenated FA and calcium soaps of long-chain FA (LCFA); and UNS = partially unsaturated FA fed as Ca soaps of LCFA.

${ }^{2}$ Trt = Treatment effect; FS = effect of FA supplement; L = linear effect of substituting unsaturated FA for saturated FA; and $\mathrm{Q}$ = quadratic effect of substituting unsaturated FA for saturated FA.

quist, 1991). Despite the net-positive FA flow expected, Jenkins (1993) observed that ruminal FA loss was reported for 15 of 47 published treatment means. Regression analysis predicted an $8 \%$ loss of FA intake, and up to a $30 \%$ FA loss was reported in the data set (Jenkins, 1993). Ferlay et al. (1993) reported a $14 \%$ increase in FA flow with control diet and 36.7 and $21.3 \%$ ruminal FA losses with rapeseed FA fed as calcium salts and triglycerides, respectively. Methodological limitations may explain some cases of ruminal FA loss as some lipids are not accounted for in traditionally used FA analysis procedures and flow marker bias may underpredict duodenal flow. Flow marker bias does not explain many situations in which duodenal flow of other nutrients are within expected ranges. Doreau and Chillard (1997) proposed that negative ruminal FA flux is not due to flow marker bias, but caused by absorption and oxidation of FA, especially with higher fat diets. Rumen epithelium and bacteria adhering to the rumen wall may be capable of oxidative metabolism of FA (Doreau and Chilliard, 1997). Doreau and Chillard (1997) noted that higher FA concentration diets experience greater FA loss and hypothesize that FA are less adsorbed to feed particles leading to increased contact with the rumen wall and increased opportunity for absorption and oxidation. In addition, increased dietary FA concentration decreases microbial FA synthesis (Jenkins, 1993), which may allow detection of ruminal FA digestion. Variation in reported rumen FA losses may be from bacterial FA synthesis, especially in low FA diets. Bacteria incorporate dietary FA into their plasma membranes and bacterial FA cannot be considered entirely from microbial production, so true FA digestibility occasionally reported in the literature has little meaning. Simple digestion studies cannot partition duodenal FA flow into dietary and microbial synthesized fractions, limiting the ability to determine the extent of rumen FA synthesis and digestion.

Table 8. Effects of fatty acid supplements varying in saturation on digestion of fatty acids (FA)

\begin{tabular}{|c|c|c|c|c|c|c|c|c|c|}
\hline & \multicolumn{4}{|c|}{ Treatment LS means $^{1}$} & \multirow[b]{2}{*}{$\mathrm{SE}$} & \multicolumn{4}{|c|}{$P^{2}$} \\
\hline & Control & SAT & INT & UNS & & TRT & FS & $\mathrm{L}$ & Q \\
\hline \multicolumn{10}{|l|}{ Total FA } \\
\hline Intake, $\mathrm{kg} / \mathrm{d}$ & 1.5 & 2.1 & 2.0 & 1.8 & 0.07 & $<0.001$ & $<0.001$ & $<0.001$ & 0.68 \\
\hline \multicolumn{10}{|l|}{ Apparently ruminally digested } \\
\hline $\mathrm{kg} / \mathrm{d}$ & 0.06 & 0.17 & 0.16 & 0.32 & 0.09 & 0.23 & 0.15 & 0.20 & 0.43 \\
\hline$\%$ & 4.0 & 7.3 & 7.9 & 18.4 & 4.9 & 0.15 & 0.19 & 0.09 & 0.38 \\
\hline Passage to duodenum, $\mathrm{kg} / \mathrm{d}$ & 1.4 & 2.0 & 1.9 & 1.5 & 0.12 & $<0.001$ & 0.003 & $<0.001$ & 0.25 \\
\hline \multicolumn{10}{|l|}{ Apparent postruminal digested } \\
\hline $\mathrm{kg} / \mathrm{d}$ & 1.0 & 1.3 & 1.3 & 1.0 & 0.11 & 0.11 & 0.12 & 0.08 & 0.31 \\
\hline$\%$ of intake & 69.1 & 59.6 & 63.0 & 56.7 & 5.2 & 0.33 & 0.12 & 0.66 & 0.42 \\
\hline$\%$ of duodenal passage & 71.5 & 63.8 & 67.9 & 69.3 & 2.5 & 0.11 & 0.09 & 0.08 & 0.62 \\
\hline \multicolumn{10}{|l|}{ Apparent total tract digested } \\
\hline $\mathrm{kg} / \mathrm{d}$ & 1.1 & 1.4 & 1.4 & 1.4 & 0.06 & $<0.001$ & $<0.001$ & 0.16 & 0.79 \\
\hline$\%$ & 73.1 & 66.9 & 70.6 & 75.1 & 1.6 & $<0.001$ & 0.15 & 0.001 & 0.80 \\
\hline
\end{tabular}

${ }^{1}$ Treatments were SAT $=$ saturated fatty acids $(\mathrm{FA})$ from prilled, hydrogenated FA; INT = intermediate saturated FA as a mix of prilled, hydrogenated FA and calcium soaps of long-chain FA (LCFA); and UNS = partially unsaturated FA fed as Ca soaps of LCFA.

${ }^{2}$ Trt = Treatment effect; FS = effect of FA supplement; L = linear effect of substituting unsaturated FA for saturated FA; and $\mathrm{Q}$ = quadratic effect of substituting unsaturated FA for saturated FA. 
Table 9. Effects of fatty acid supplements varying in saturation on digestion of $\mathrm{C} 16$ and C18 fatty acids (FA)

\begin{tabular}{|c|c|c|c|c|c|c|c|c|c|}
\hline & \multicolumn{4}{|c|}{ Treatment LS means ${ }^{1}$} & \multirow[b]{2}{*}{$\mathrm{SE}$} & \multicolumn{4}{|c|}{$P^{2}$} \\
\hline & Control & SAT & INT & UNS & & TRT & FS & $\mathrm{L}$ & $\mathrm{Q}$ \\
\hline \multicolumn{10}{|l|}{ Total C16 FA } \\
\hline Intake, $\mathrm{kg} / \mathrm{d}$ & 0.28 & 0.50 & 0.47 & 0.44 & 0.02 & $<0.001$ & $<0.001$ & 0.001 & 0.96 \\
\hline \multicolumn{10}{|l|}{ Apparently ruminally digested } \\
\hline $\mathrm{kg} / \mathrm{d}$ & -0.01 & 0.05 & 0.04 & 0.09 & 0.03 & 0.06 & 0.02 & 0.23 & 0.32 \\
\hline$\%$ & -3.8 & 9.1 & 8.0 & 20.0 & 6.2 & 0.05 & 0.02 & 0.16 & 0.34 \\
\hline Passage to duodenum, kg/d & 0.30 & 0.45 & 0.43 & 0.35 & 0.03 & $<0.001$ & $<0.001$ & 0.006 & 0.28 \\
\hline \multicolumn{10}{|l|}{ Apparent postruminal digested } \\
\hline $\mathrm{kg} / \mathrm{d}$ & 0.23 & 0.31 & 0.30 & 0.24 & 0.03 & 0.08 & 0.07 & 0.08 & 0.38 \\
\hline$\%$ of intake & 81.6 & 62.8 & 64.8 & 56.0 & 6.5 & $<0.05$ & $<0.01$ & 0.41 & 0.47 \\
\hline$\%$ of duodenal passage & 77.9 & 68.4 & 70.1 & 69.5 & 2.6 & 0.06 & 0.008 & 0.74 & 0.71 \\
\hline \multicolumn{10}{|l|}{ Apparent total tract digested } \\
\hline $\mathrm{kg} / \mathrm{d}$ & 0.22 & 0.36 & 0.34 & 0.33 & 0.02 & $<0.001$ & $<0.001$ & 0.12 & 0.85 \\
\hline$\%$ & 77.9 & 71.9 & 73.2 & 76.0 & 1.6 & 0.03 & 0.02 & 0.04 & 0.66 \\
\hline \multicolumn{10}{|l|}{ Total C18 FA } \\
\hline Intake, kg/d & 1.0 & 1.4 & 1.3 & 1.2 & 0.05 & $<0.001$ & $<0.001$ & $<0.001$ & 0.55 \\
\hline \multicolumn{10}{|l|}{ Apparently ruminally digested } \\
\hline $\mathrm{kg} / \mathrm{d}$ & 0.09 & 0.13 & 0.14 & 0.13 & 0.05 & 0.30 & 0.27 & 0.16 & 0.53 \\
\hline$\%$ & 9.6 & 8.8 & 10.7 & 20.3 & 4.5 & 0.19 & 0.46 & 0.06 & 0.46 \\
\hline Passage to duodenum, kg/d & 0.9 & 1.2 & 1.2 & 0.9 & 0.07 & $<0.001$ & 0.005 & $<0.001$ & 0.25 \\
\hline \multicolumn{10}{|l|}{ Apparent postruminal digested } \\
\hline $\mathrm{kg} / \mathrm{d}$ & 0.64 & 0.78 & 0.79 & 0.66 & 0.07 & 0.16 & 0.15 & 0.14 & 0.30 \\
\hline$\%$ of intake & 64.0 & 57.3 & 60.7 & 55.9 & 4.7 & 0.57 & 0.26 & 0.82 & 0.46 \\
\hline$\%$ of duodenal passage & 70.4 & 62.4 & 67.5 & 70.0 & 2.5 & 0.05 & 0.15 & 0.02 & 0.64 \\
\hline \multicolumn{10}{|l|}{ Apparent total tract digested } \\
\hline $\mathrm{kg} / \mathrm{d}$ & 0.75 & 0.91 & 0.91 & 0.89 & 0.04 & $<0.001$ & $<0.001$ & 0.73 & 0.60 \\
\hline$\%$ & 73.5 & 66.1 & 70.9 & 76.2 & 1.6 & $<0.001$ & 0.11 & $<0.001$ & 0.89 \\
\hline
\end{tabular}

${ }^{1}$ Treatments were SAT $=$ saturated fatty acids $(\mathrm{FA})$ from prilled, hydrogenated FA; INT = intermediate saturated FA as a mix of prilled, hydrogenated FA and calcium soaps of long-chain FA (LCFA); and UNS = partially unsaturated FA fed as Ca soaps of LCFA.

${ }^{2}$ Trt = Treatment effect; FS = effect of FA supplement; L = linear effect of substituting unsaturated FA for saturated FA; and Q = quadratic effect of substituting unsaturated FA for saturated FA.

Investigations of ruminal FA loss have not considered effects of FA saturation. Increased ruminal disappearance of unsaturated FA observed in the current study may represent increased metabolism of unsaturated FA, and many reports of ruminal FA loss were unsaturated FA treatments (Wu et al., 1991; Ferlay et al., 1993). It is reasonable that unsaturated FA may be more highly oxidized in the rumen because they are less hydrophobic than saturated FA and are more dispersed in the rumen allowing increased contact with ruminal bacteria. In addition, ruminal bacteria absorb unsaturated FA during biohydrogenation. Unsaturated FA that are absorbed in excess of bacterial requirements for cellular membranes might be oxidized to eliminate their toxic effect. Fatty acid saturation and concentration in the diet might explain the inconsistent ruminal FA loss noted by Jenkins (1993). The common occurrence of ruminal FA loss reported in digestion studies merits investigation of ruminal FA metabolism.

Digestibility of total FA as a percentage of duodenal FA flow tended to decrease and C16 FA digestibility decreased with FS. Increasing saturated FS tended to decrease total FA digestibility and decreased C18 FA digestibility as a proportion of FA flowing to the duodenum. Total tract digestibility of total FA was not affected by FS, but increasing saturated FS linearly reduced total, C16 and C18 FA digestibility. Saturated FS increased duodenal flow of FA but UNS did not change FA flow compared with the control because of decreased intake and increased ruminal FA loss. Within FS, increasing saturated FS linearly increased duodenal FA flow because of increased intake, less ruminal FA disappearance and unintentionally higher dietary FA concentration (see discussion of treatments in Harvatine and Allen, 2006a). Amount of total and C16 FA digested postruminally tended to increase with increasing saturated FS. Postruminal digestion of total and C18 FA as a percentage of intake was not different across treatments, because of differences in ruminal digestion. This shows equal efficiency of capturing dietary FA energy between SAT and UNS. Treatment did not affect total tract total digestibility of total FA and C16 FA but decreased total tract digestibility of C18 FA for noncannulated cows on the same diets (Harvatine and Allen, 2006a). Differences in FA digestibility reported in the literature are biased because of ruminal 
FA loss, differences in esterification, biohydrogenation in the large intestine, and oxidation of unsaturated FA before analysis. Total tract digestibility of esterified FA is lower than that of unesterified FA (Elliott et al., 1994, 1999), and triglyceride digestibility decreases with increasing saturation (Pantoja et al., 1995,1996). Elliott et al. (1999) observed that highly saturated triglycerides are more resistant to ruminal and intestinal lipolysis, resulting in lower digestibility. Decreased ruminal lipolysis of saturated triglyceride increases duodenal flow of esterified FA. The low $\mathrm{pH}$ of the duodenum inhibits lipase function and esterified FA are not hydrolyzed until the jejunum, decreasing the opportunity for FA absorption (Noble, 1981; Drackley, 2000). Decreased ruminal lipolysis of saturated FA increases duodenal flow of esterified FA. The belief that saturated FA are less digestible may be an erroneous conclusion based on decreased total tract digestibility of saturated esterified FA.

Sample handling and preparation may bias digestibility calculation because of partial oxidation of FA (D. L. Palmquist, The Ohio State University, OARDC, Wooster, personal communication). In the current study, samples were flushed with nitrogen gas and frozen to minimize sample oxidation. However, the methylation procedure of Sukhija and Palmquist (1988) may also cause partial loss of unsaturated FA. Oxidation of unsaturated FA from improper storage and sample preparation decreases unsaturated FA concentration, leading to an overprediction of unsaturated FA digestibility compared with saturated FA, which are much less prone to oxidation.

Data for total tract and intestinal digestibility of individual FA support decreased digestibility of saturated FA compared with unsaturated FA. However, measures for individual FA are meaningless because of FA biohydrogenation and synthesis in the large intestine (Merchen et al., 1997), which results in an overprediction of unsaturated FA digestibility. Digestibility of individual FA can only be determined with duodenally and ileally cannulated cows but the cost and complexity of multiple intestinal cannulations has limited such measures. However, digestibility of unsaturated FA can be compared with saturated FA by observing total, C16, or C18 FA digestibility between treatments differing in duodenal FA profile. Christensen et al. (1994) and Bremmer et al. (1998) measured digestibility of total FA for abomasally infused free FA and observed no difference between saturated and unsaturated FA treatments. Schauff and Clark (1989), Grummer (1988), and Palmquist (1991) directly compared calcium salts of palm FA and prilled, saturated free FA, finding no difference in total tract digestibility of energy, lipid, and FA. Elliott et al. (1996) observed lower (8 percent- age units) total tract FA digestibility with prilled FA compared with calcium salts of palm FA, although treatments were not compared in the statistical contrasts. Doreau and Chilliard (1997) summarized 64 treatment groups reporting FA digestibility in the small intestine or the lower tract, finding no difference between C16 and C18 FA, and observed only slight differences between lower tract saturated and unsaturated C18 FA digestibility $(77,85,83$, and $76 \%$ for $0,1,2$, and 3 double bonds, respectively). The difference in saturated and unsaturated FA digestibility reported in the literature is small, especially considering the possible biases.

Lastly, true loss of ruminal FA discounts the value of measurement of total tract digestibility. Increased ruminal digestion may increase total tract FA digestibility without increasing energy available to the animal. If unsaturated FA are more highly degraded in the rumen, increased unsaturated FA digestion in the total tract might not increase intestinal FA absorption. The energy efficiency of ruminally digested FA is not known, but considerable energy loss is expected because of bacterial maintenance energy requirements and loss of energy in chemical transformation. Digestion studies have reported substantial ruminal FA digestion (Wu et al., 1991; Ferlay et al., 1993), which may have a large effect on energy absorption, especially considering the high energy value of FA. Merchen et al. (1997) proposed that fat digestion experiments should use duodenally cannulated animals for observation of duodenal FA profile and calculation of ruminal and postruminal digestibility as is common in starch and fiber digestion studies.

Saturated FS linearly decreased digestibility of C18 FA flowing to the duodenum by 7.6 percentage units compared with UNS; we have previously reported a 4.2percentage unit decrease in total tract digestibility with noncannulated cows on the same diets (Harvatine and Allen, 2006a). In the current experiment, postruminal C18 FA digestibility of UNS was not different from control but was decreased by SAT. Decreased FA digestibility of SAT cannot be directly attributed to lower digestibility of C18:0 because control and SAT did not differ in duodenal C18:0 composition. Fatty acid digestion across FS saturation may be a result of the amount of duodenal FA or DM flow. Schauff and Clark (1992) reported decreased FA digestibility as the FA content of the diet was increased with dietary calcium salts of palm FA, but Jenkins (1999) reported a linear increase in total tract FA digestibility when oleamide was increased from 0 to $5 \%$ of the diet. Palmquist (1991) discussed decreased FA digestibility with increasing duodenal flow and reported drastic decreases in true and marginal true digestibility with increasing FA intake, 
noting a 4.4-percentage unit decrease in marginal true FA digestibility (digestibility of each increment of fatty acid consumed) per $100 \mathrm{~g}$ of FA intake. Weisbjerg et al. (1992a,b) observed decreased FA digestibility when increasing FA intake from 500 to $1000 \mathrm{~g} / \mathrm{d}$ of palmitic and stearic acid, and when increasing FA intake from tallow. Analysis of the relationship between FA digestibility and FA intake is confounded by FA form and saturation used to increase FA intake, making conclusions difficult.

The associative effects among feed intake, digesta passage rate, and diet composition on FA digestibility have received little attention. Grum et al. (1996) reported a large decrease ( $>23.9$ percentage units) in C18 FA digestibility with increased concentrate feeding with and without tallow. Elliott et al. (1995) observed increased total tract FA digestibility in diets that replaced ground corn with soyhulls. Weisbjerg et al. (1992b) did not observe any difference in tallow FA intake at low $(8.6 \mathrm{~kg})$ and high $(12.6 \mathrm{~kg}) \mathrm{DMI}$, although both intake levels were considerably lower than observed in the current study. Associative effects of dietary carbohydrates on FA digestibility are not known but may include level of DM intake as well as duodenal digesta flow rate and composition.

\section{CONCLUSIONS}

Saturated fat supplement decreased ruminal NDF digestibility possibly because increased rumination resulted in a faster passage of more rapidly fermentable NDF. Saturated fat supplement also decreased FA digestibility, although it is not possible to discern if it is because of FA composition or increased flow of FA to the duodenum. Addition of fat supplements may not increase energy intake because of decreased DMI and negative associative effects on ruminal digestion of NDF. Effects of fat supplements on feed intake can have a much greater effect on digestible energy intake than modest differences in FA digestibility.

\section{ACKNOWLEDGMENTS}

We wish to acknowledge MS Specialty Nutrition (Dundee, IL) for partial financial support of this research. We also thank N. K. Ames for performing duodenal and ruminal cannulations, and D. G. Main, R. A. Longuski, Y. Ying, M. Oba, C. S. Mooney, J. A. Voelker, C. C. Taylor, R. E. Kreft, and the staff of the Michigan State University Dairy Cattle Teaching and Research Center for their assistance in this experiment.

\section{REFERENCES}

Allen, M. S. 1996. Physical constraints on voluntary intake of forages by ruminants. J. Anim. Sci. 74:3063-3075.
Allen, M. S. 2000. Effects of diet on short-term regulation of feed intake by lactating dairy cattle. J. Dairy Sci. 83:1598-1624.

Bremmer, D. R., L. D. Ruppert, J. H. Clark, and J. K. Drackley. 1998. Effects of chain length and unsaturation of fatty acid mixtures infused into the abomasum of lactating dairy cows. J. Dairy Sci. 81:176-188.

Chalupa, W., B. Rickabaugh, D. S. Kronfeld, and D. Sklan. 1984. Rumen fermentation in vitro as influenced by long-chain fatty acids. J. Dairy Sci. 67:1439-1444.

Chan, S. C., J. T. Huber, C. B. Theurer, Z. Wu, K. H. Chen, and J. M. Simas. 1997. Effects of supplemental fat and protein source on ruminal fermentation and nutrient flow to the duodenum in dairy cows. J. Dairy Sci. 80:152-159.

Christensen, R. A., J. K. Drackley, D. W. LaCount, and J. H. Clark. 1994. Infusion of four long-chain fatty acid mixtures into the abomasum of lactating dairy cows. J. Dairy Sci. 77:1052-1069.

Crocker, L. M., E. J. DePeters, J. G. Fadel, H. Perez-Monti, S. J. Taylor, J. A. Wyckoff, and R. A. Zinn. 1998. Influence of processed corn grain in diets of dairy cows on digestion of nutrients and milk composition. J. Dairy Sci. 81:2394-2407.

Doreau, M., and Y. Chilliard. 1997. Digestion and metabolism of dietary fat in farm animals. Br. J. Nutr. 78(Suppl. 1):S15-S35.

Drackley, J. K. 2000. Lipid Metabolism. Pages 97-119 in Farm animal metabolism and nutrition. J. P. F. D’Mello, ed. CABI Publ., Wallingford, UK.

Eastridge, M. L., and J. L. Firkins. 1991. Feeding hydrogenated fatty acids and triglycerides to lactating dairy cows. J. Dairy Sci. 74:2610-2616.

Elliott, J. P., J. K. Drackley, C. G. Aldrich, and N. R. Merchen. 1997. Effects of saturation and esterification of fat sources on site and extent of digestion in steers: Ruminal fermentation and digestion of organic matter, fiber, and nitrogen. J. Anim. Sci. 75:2803-2812.

Elliott, J. P., J. K. Drackley, A. D. Beaulieu, C. G. Aldrich, and N. R. Merchen. 1999. Effects of saturation and esterification of fat sources on site and extent of digestion in steers: Digestion of fatty acids, triglycerides, and energy. J. Anim. Sci. 77:1919-1929.

Elliott, J. P., J. K. Drackley, G. C. Fahey, Jr., and R. D. Shanks. 1995. Utilization of supplemental fat by dairy cows fed diets varying in content of nonstructural carbohydrates. J. Dairy Sci. 78:1512-1525.

Elliott, J. P., J. K. Drackley, and D. J. Weigel. 1996. Digestibility and effects of hydrogenated palm fatty acid distillate in lactating dairy cows. J. Dairy Sci. 79:1031-1039.

Elliott, J. P., T. R. Overton, and J. K. Drackley. 1994. Digestibility and effects of three forms of mostly saturated fatty acids. J. Dairy Sci. 77:789-798.

Ferlay, A., J. Chabrot, Y. Elmeddah, and M. Doreau. 1993. Ruminal lipid balance and intestinal digestion by dairy cows fed calcium salts of rapeseed oil fatty acids or rapeseed oil. J. Anim. Sci. 71:2237-2245.

Goering, H. H., and P. J. Van Soest. 1970. Forage Fiber Analysis (Apparatus, Reagents, Procedures, and Some Applications). Agric. Handbook No. 379. ARS-USDA, Washington, DC.

Grum, D. E., J. K. Drackley, L. R. Hansen, and J. D. Cremin, Jr. 1996. Production, digestion, and hepatic lipid metabolism of dairy cows fed increased energy from fat or concentrate. J. Dairy Sci. 79:1836-1849.

Grummer, R. R. 1988. Influence of prilled fat and calcium salt of palm oil fatty acids on ruminal fermentation and nutrient digestibility. J. Dairy Sci. 71:117-123.

Hach, C. C., B. K. Bowden, A. B. Lopelove, and S. V. Brayton. 1987. More powerful peroxide Kjeldahl digestion method. J. AOAC 70:783-787.

Harfoot, C. G. 1981. Lipid metabolism in the rumen. Pages $21-55$ in Lipid metabolism in ruminant animals. 1st ed. W. W. Christie, ed. Pergamon Press, Oxford, UK.

Harvatine, K. J., and M. S. Allen. 2006a. Effects of fatty acid supplements on milk yield and energy balance of lactating dairy cows. J. Dairy Sci. 89:1081-1091.

Harvatine, K. J., and M. S. Allen. 2006b. Effects of fatty acid supplements on feed intake, and feeding and chewing behavior of lactating dairy cows. J. Dairy Sci. 89:1104-1112. 
Harvatine, K. J., and M. S. Allen. 2006c. Effect of fatty acid supplements on fractional rate of ruminal biohydrogenation in lactating dairy cows. J. Nutr. (accepted)

Jenkins, T. C. 1993. Lipid metabolism in the rumen. J. Dairy Sci. 76:3851-3863.

Jenkins, T. C. 1999. Lactation performance and fatty acid composition of milk from Holstein cows fed 0 to $5 \%$ oleamide. J. Dairy Sci. 82:1525-1531.

Karkalas, J. 1985. An improved enzymatic method for the determination of native and modified starch. J. Sci. Food Agric. 36:10191027.

Merchen, N. R., J. C. Elizalde, and J. K. Drackley. 1997. Current perspective on assessing site of digestion in ruminants. J. Anim. Sci. 75:2223-2234

National Research Council. 2001. Nutritional Requirements of Dairy Cattle. 7th rev. ed. Natl. Acad. Sci., Washington, DC.

Noble, R. C. 1981. Digestion, absorption, and transport of lipids in ruminant animals. Pergamon Press, Oxford, UK.

Oba, M., and M. S. Allen. 2003a. Effects of corn grain conservation method on feeding behavior and productivity of lactating dairy cows at two dietary starch concentrations. J. Dairy Sci. $86: 174-183$

Oba, M., and M. S. Allen. 2003b. Effects of corn grain conservation method on ruminal digestion kinetics for lactating dairy cows at two dietary starch concentrations. J. Dairy Sci. 86:184-194.

Palmquist, D. L. 1991. Influence of source and amount of dietary fat on digestibility in lactating cows. J. Dairy Sci. 74:1354-1360

Pantoja, J., J. L. Firkins, and M. L. Eastridge. 1995. Site of digestion and milk production by cows fed fats differing in saturation, esterification, and chain length. J. Dairy Sci. 78:2247-2258.

Pantoja, J., J. L. Firkins, and M. L. Eastridge. 1996. Fatty acid digestibility and lactation performance by dairy cows fed fats varying in degree of saturation. J. Dairy Sci. 79:429-437.

Robinson, P. H., C. J. Sniffen, and D. F. Smith. 1985. Development of a one-piece reentrant cannula for the proximal duodenum of dairy cows. J. Dairy Sci. 68:986-995.
SAS Institute. 2003. JMP. User's Guide: Statistical Discovery Software. Version 5 ed. SAS Inst., Inc., Cary, NC.

Schauff, D. J., and J. H. Clark. 1989. Effects of prilled fatty acids and calcium salts of fatty acids on rumen fermentation, nutrient digestibilities, milk production, and milk composition. J. Dairy Sci. 72:917-927.

Schauff, D. J., and J. H. Clark. 1992. Effects of feeding diets containing calcium salts of long-chain fatty acids to lactating dairy cows. J. Dairy Sci. 75:2990-3002.

Sukhija, P. S., and D. L. Palmquist. 1988. Rapid method for determination of total fatty acid content and composition of feedstuffs and feces. J. Agric. Food Chem. 36:1202-1206.

Van Soest, P. J., J. B. Robertson, and B. A. Lewis. 1991. Methods for dietary fiber, neutral detergent fiber, and nonstarch polysaccharides in relation to animal nutrition. J. Dairy Sci. 74:35833597.

Weisbjerg, M. R., C. F. Borsting, and T. Hvelplund. 1992. Fatty acid metabolism in the digestive tract of lactating cows fed tallow in increasing amounts at two feed levels. Acta Agric. Scand., A Anim. Sci. 42:106-114.

Weisbjerg, M. R., T. Hvelplund, and C. F. Borsting. 1992. Digestibility of fatty acids in the gastrointestinal tract of dairy cows fed with tallow or saturated fats rich in stearic acid or palmitic acid. Acta Agric. Scand., A Anim. Sci. 42:115-120.

Williams, C. H., D. J. David, and O. Iismaa. 1962. The determination of chromic oxide in feces samples by atomic absorption spechtophotometry. J. Agric. Sci. 59:381-385.

Williams, G. L., and R. L. Stanko. 1999. Dietary fats as reproductive nutraceuticals in beef cattle. J. Anim. Sci. http://www.asas.org/ jas/symposia/proceeding/0915.pdf

Wu, Z., O. A. Ohajuruka, and D. L. Palmquist. 1991. Ruminal synthesis, biohydrogenation, and digestibility of fatty acids by dairy cows. J. Dairy Sci. 74:3025-3034.

Wu, Z., and D. L. Palmquist. 1991. Synthesis and biohydrogenation of fatty acids by ruminal microorganisms in vitro. J. Dairy Sci. 74:3035-3046. 